\title{
Response of Potato (Solanum tuberosum L.) to NPS Fertilizer Rates and Inter-Row Spacing in Kechi District, South Western Ethiopia
}

\author{
Lakew Getaneh (D) and Fanuel Laekemariam \\ Wolaita Sodo University, College of Agriculture, P.O.Box 138, Wolalita Sodo, Ethiopia \\ Correspondence should be addressed to Lakew Getaneh; lakget@gmail.com
}

Received 6 February 2021; Revised 26 August 2021; Accepted 9 September 2021; Published 5 October 2021

Academic Editor: Claudio Cocozza

Copyright (c) 2021 Lakew Getaneh and Fanuel Laekemariam. This is an open access article distributed under the Creative Commons Attribution License, which permits unrestricted use, distribution, and reproduction in any medium, provided the original work is properly cited.

\begin{abstract}
Fertilizer requirement and spacing vary across locations due to differences in soil types, nutrient and moisture availability, economic factors, and other environmental conditions. Therefore, a field experiment was carried out to investigate the effect of different rates of NPS fertilizers and inter-row spacing on growth, yield, yield components, and economic performance of potato in Kechi research farm, Dawro zone of south-western Ethiopia. The experiment was arranged in factorial combination of six NPS (19N-38P2O5-7S) fertilizer rates (0 kg/ha, $50 \mathrm{~kg} / \mathrm{ha}, 100 \mathrm{~kg} / \mathrm{ha}, 150 \mathrm{~kg} / \mathrm{ha}, 200 \mathrm{~kg} / \mathrm{ha}$, and $250 \mathrm{~kg} / \mathrm{ha})$ and five interrow spacings $(45,55,65,75$, and $85 \mathrm{~cm})$ which were laid out in RCBD with three replications using the Gudene variety. Growth, yield component, and yield data were collected and analyzed. In addition, a partial budget analysis was performed. The results showed that the main effect of NPS fertilizer and inter-row spacing had significantly $(P<0.05)$ affected plant height, tuber number, tuber yield, and tuber size and average tuber weight. Maximum marketable tuber number per plant (11.627), total tuber number per plant (13.020), average tuber weight per plant $(83.493 \mathrm{~g})$, the proportion of large-sized tuber number per plant $(41.893 \%)$, marketable tuber yield $(48.056 \mathrm{t} / \mathrm{ha})$, and total tuber yield $(51.145 \mathrm{t} / \mathrm{ha})$ were obtained from $200 \mathrm{~kg} / \mathrm{ha}$ of NPS fertilizer which was statistically at par with $150 \mathrm{~kg} / \mathrm{ha}$ and $250 \mathrm{~kg} / \mathrm{ha}$ NPS, while the lowest result for those parameters was recorded from unfertilized plots. Results regarding inter-row spacing revealed that the highest marketable tuber number per plant (11.744), total tuber number per plant (13.144), and average tuber weight per plant $(85.559 \mathrm{~g})$ were recorded at $75 \mathrm{~cm}$, while the lowest result for these parameters was recorded at $45 \mathrm{~cm}$. Moreover, the highest marketable tuber yield (45.084 t/ha) and total tuber yield $(48.462 \mathrm{t} / \mathrm{ha})$ were obtained from the inter-row spacing of $65 \mathrm{~cm}$ which was statistically at par with $55 \mathrm{~cm}$ inter-row spacing, while the lowest result for these parameters was recorded at $85 \mathrm{~cm}$. The partial budget analysis further revealed that $200 \mathrm{~kg} / \mathrm{ha}$ NPS fertilizer gave the maximum net benefit. However, $150 \mathrm{~kg} / \mathrm{ha}$ NPS resulted in the highest marginal rate of return (4303.91\%). Thus, $150 \mathrm{~kg} / \mathrm{ha}$ NPS fertilizer and inter-row spacing of $55 \mathrm{~cm}$ or $65 \mathrm{~cm}$ are suggested for attaining higher potato yield.
\end{abstract}

\section{Introduction}

Potato (Solanum tuberosum L.) is the world's most important root and tuber crop after rice, wheat, and maize and has historically contributed to food and nutrition security in the world $[1,2]$. Potato tubers are not only rich in carbohydrates but also a mineral resource for consumption; also, the food needs of half a billion people in the world $[1,2]$. The annual production of the world and Africa in the year of 2018 was about 368.2 and 26 million tons, respectively [3].

Potato (Solanum tuberosum L.) is the third most important food crop in the world after rice and wheat in terms of human consumption. More than a billion people eat potato worldwide, and global total production exceeds 300 million metric tons. There are more than 4,000 varieties of native potato and also over 180 wild species, mostly found in the Andes [4]. In central highlands of Ethiopia, an 
adaptation trial of potato was conducted to identify potato varieties that are better for adaptation, yield, and other agronomic traits and disease tolerance. The national average potato yield in Ethiopia is $13.9 \mathrm{t} \mathrm{ha}^{-1}$ [5], which is lower than world average yield up to $20 \mathrm{t} \mathrm{ha}^{-1}$ [6]. Annual potato production in Ethiopia has increased from 349,000 tons in 1993 to around 743, 153 tons in 2018 [3] and can potentially be grown on about $70 \%$ of arable land in the country.

Potato producers in Ethiopia use poor agronomic practices which include inadequate land preparation, suboptimal plant population, and fertilizer application [7, 8]. Among agronomic practices, spacing deserves special attention. Optimum spacing varies with soil fertility status, soil moisture, the nature of the crop, and degree of weed infestation $[9,10]$. Blanket spacing recommended in Ethiopia for ware potato production was $75 \mathrm{~cm}$ between rows and $30 \mathrm{~cm}$ between plants. Yet, research evidence from different parts of the country indicated an inter-row spacing of $50 \mathrm{~cm}$ and $60 \mathrm{~cm}$ in Eastern Ethiopia [11] and $65 \mathrm{~cm}$ in North Ethiopia [12]. The variation in plant spacing at different locations according to the scholars was associated with soil type, soil fertility status, plant architecture or growth habit, soil moisture, rainfall, nutrient availability, and other environmental conditions. This recalls the need to develop sitespecific recommendations.

Apart from spacing, soil nutrient status is also the most important parameter that limits the yielding potentials of various crops including potato. It was evident that sources of plant nutrients for Ethiopian agriculture over the past five decades have been limited to urea $(46 \mathrm{~N})$ and diammonium phosphate (DAP) fertilizers $\left(18 \mathrm{~N}-46 \mathrm{P}_{2} \mathrm{O}_{5}\right)$ which contain only nitrogen $(\mathrm{N})$ and phosphorus $(\mathrm{P})$. It was supplied based on the blanket approach without taking site-specific variability into consideration. These might have led to the depletion of other important essential elements [13] and consequently not satisfy the nutrient requirements of crops including potato. Soil fertility survey made over 150 districts in Ethiopia indicated that soil lacks about seven nutrients $(\mathrm{N}$, $\mathrm{P}$, potassium $(\mathrm{K})$, sulfur $(\mathrm{S})$, copper $(\mathrm{Cu})$, zinc $(\mathrm{Zn})$, and boron (B)) [14]. Shiferaw [15] also reported that Ethiopian soils lack most of the macro- and micronutrients that are required to sustain optimal growth and development of crops. Reference [16] in soils of Southern Ethiopian also reported the limitation of $\mathrm{N}, \mathrm{P}, \mathrm{K}, \mathrm{S}, \mathrm{B}$, and $\mathrm{Cu}$. To fill such gaps, the Ministry of Agriculture of Ethiopia introduced a new compound fertilizer NPS (19\% N, 38\% $\mathrm{P}_{2} \mathrm{O}_{5}$, and $\left.7 \% \mathrm{~S}\right)$ instead of DAP.

Though, site-specific information regarding NPS fertilizer is scanty, emerging evidence indicated varied rates of NPS fertilizer. For instance, Melkamu and Minwyelet [17] from Northwestern Ethiopia reported the amount ranged from $136.20 \mathrm{~kg} / \mathrm{ha}$ to $283.75 \mathrm{~kg} / \mathrm{ha}$ NPS which was attributed to soil nutrient status, variety, and location. Reference [18] recommend 55.5:89.7:16.52akg/ha $\mathrm{N}: \mathrm{P}_{2} \mathrm{O}_{5}: \mathrm{S}$ fertilizer rate application for optimum production of potato at Dessie Zuria District, Ethiopia. Thus, generating site-specific NPS rate is suggested.

Despite the fact that many farmers in Ethiopia have been growing potato, limited information with respect to the intrarow spacing, NPS fertilizer rate and their interaction effects on potato crop is documented. Thus, the present study examined the hypothesis that potato crop responded to the varied rate of NPS fertilizers and inter-row spacing. Therefore, the objectives of the study were to investigate the effect of different rate of NPS fertilizers and inter-row spacing on growth, yield, yield components, and economic performance of potato and to determine appropriate interrow spacing and NPS fertilizers rate for economic yield production.

\section{Materials and Methods}

2.1. Description of the Study Area. The study was conducted on a research farm of Kechi (Dawro zone), south-western Ethiopia (Figure 1). The Kechi farm lies between $7^{\circ} 5^{\prime} 37.98^{\prime \prime} \mathrm{N}$ to $7^{\circ} 1^{\prime} 4.11^{\prime \prime} \mathrm{N}$ latitude and $36^{\circ} 57^{\prime} 5.45^{\prime \prime} \mathrm{E}$ to $37^{\circ} 0^{\prime} 26.56^{\prime \prime} \mathrm{E}$ longitude with an average altitude of 2090 m.a.s.l. The farm has diverse topographies covering an area of 131.26 ha and with mean monthly temperature ranging from $14^{\circ} \mathrm{C}$ to $24^{\circ} \mathrm{C}$. The annual rainfall of the area varies from 1443 to $2535 \mathrm{~mm}$ (Figure 2). The soil type of the area is Luvisols. The soil textural class where the field experiment conducted was silty clayey loam.

2.2. Sample Preparation and Soil Analysis. Soil sample was collected at a depth of $0-20 \mathrm{~cm}$ with 10 subsamples to make a composited soil sample. It was processed (air-dried, ground, and passed through 2 and $0.5 \mathrm{~mm}$ sieves) and analyzed for selected chemical and physical properties following the standard procedure. Particle size distribution analysis for textural class determination was conducted by the Bouyoucos hydrometer method with Marshall's triangular coordinate system $[20,21]$. Soil $\mathrm{pH}$ was measured using a glass electrode $\mathrm{pH}$ meter with a ratio of $1: 2.5$ soil to water [21]. The soil organic carbon (OC) content was determined by the wet oxidation method (Walkley and Black,1934) and the total nitrogen (TN) content by the Kjeldahl Method [22]; available $\mathrm{P}, \mathrm{K}$, and $\mathrm{S}$ were determined using the Mehlich 3 method [23]. The soil physical and chemical properties of the experimental field are presented in Table 1.

\subsection{Experimental Material, Treatments, and Experimental} Design. Potato variety "Gudanie (CIP-386423.13)" was used as a test crop. Gudene was released by Holetta Agricultural Research Center in 2006. It has specific adaptation from 1600 to 2800 m.a.s.l., with a rainfall range of $1000-1500 \mathrm{~mm}$. NPS $\left(19 \mathrm{~N}-38 \mathrm{P}_{2} \mathrm{O}_{5}-7 \mathrm{~S}\right)$ and urea $(46 \% \mathrm{~N})$ fertilizers were used as a source of $\mathrm{N}, \mathrm{P}$, and $\mathrm{S}$ nutrients.

The experiment had two factors, namely, NPS rates and inter-row spacing. The treatments consisted of six levels of NPS $(\mathrm{kg} / \mathrm{ha})(0,50,100,150,200$, and 250$)$ and five inter-row spacings $(\mathrm{cm})(45,55,65,75$, and 85$)$. The experiment was laid out in randomized complete block design (RCBD) in a factorial arrangement with three replications. The gross plot size was $4.55 \mathrm{~m} \times 3.6 \mathrm{~m}\left(16.38 \mathrm{~m}^{2}\right)$ accommodating $10,8,7$, 6 , and 5 rows for $45,55,65,75$, and $85 \mathrm{~cm}$ inter-rows, 


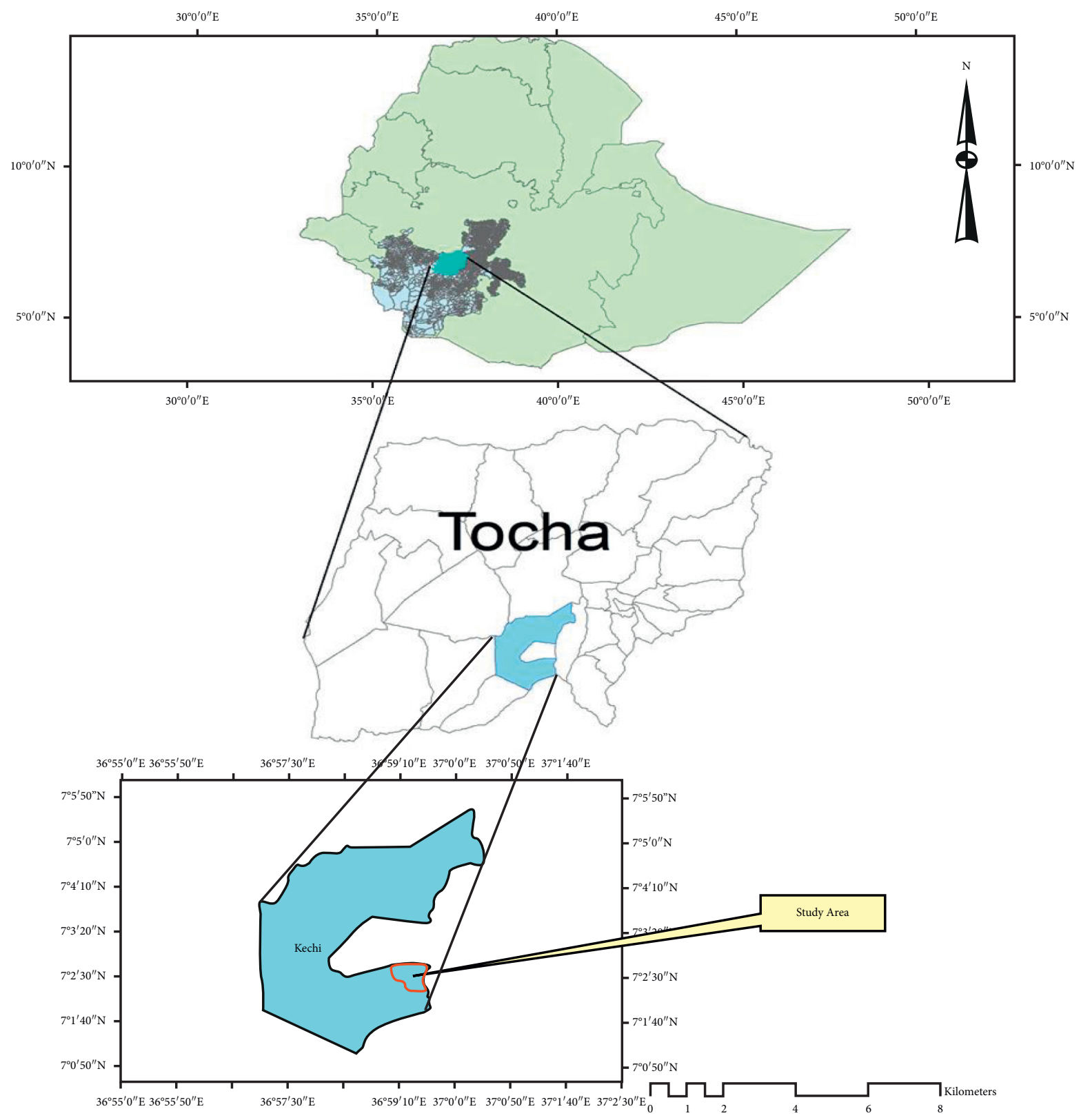

Figure 1: Map of the study area.

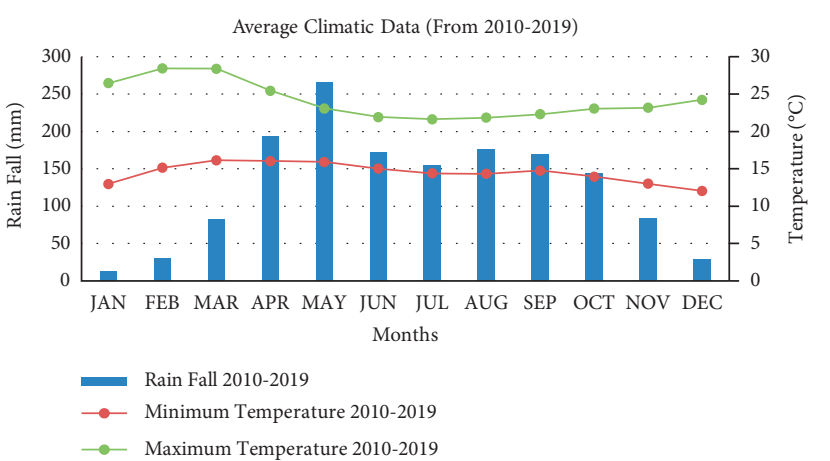

Figure 2: Climatic data of Kechi (source: [19]). respectively. The blocks were separated by $1.5 \mathrm{~m}$ wide space, and each plot was separated by $1 \mathrm{~m}$ space.

2.4. Field Management. The experimental field was ploughed four times prior sowing. Medium-sized and well-sprouted tubers were planted at the sides of ridges at $30 \mathrm{~cm}$ intrarow spacing and the respective inter-row spacing. Based on the treatments, the total quantity of NPS fertilizer was applied at the time of planting. Nitrogen fertilizer was applied in the form of urea in two splits 25 and 50 days after planting for each treatment. Other cultural practices such as weeding, hoeing, and plant protection methods were done uniformly for all experimental plots as recommended by EIAR [26]. 
TABLE 1: Major soil characteristics of the experimental site.

\begin{tabular}{|c|c|c|c|}
\hline Soil characteristics & Values & Rating & Reference \\
\hline \multicolumn{4}{|l|}{ Particle size } \\
\hline Sand $(\%)$ & 20 & - & \\
\hline Silt (\%) & 44 & - & \\
\hline Clay (\%) & 36 & - & \\
\hline Textural class & & Silt clay loam & \\
\hline Soil pH & 5.6 & Moderately acidic (5.6-6.5) & {$[24]$} \\
\hline Organic carbon (\%) & 2.79 & Low $(2-4 \%)$ & [25] \\
\hline Total, $N(\%)$ & 0.28 & Medium (0.21-0.5\%) & {$[25]$} \\
\hline Available P (mg/kg) & 19.12 & Low $(15-30)$ & {$[24]$} \\
\hline Available $\mathrm{K}(\mathrm{mg} / \mathrm{kg})$ & 365.51 & Optimum (190-600) & {$[24]$} \\
\hline Available S (mg/kg) & 4.82 & Very low $(<10)$ & {$[24]$} \\
\hline
\end{tabular}

2.5. Data Collection and Analysis. Growth- and yield-related parameters were collected from the net plot area of each plot to avoid border effects using the standard procedures described as follows. Growth parameter considered was plant height; crop phenology parameters include days to reach $50 \%$ flowering and $90 \%$ maturity, while yield parameters recorded include number of marketable, unmarketable, and total tubers, tuber size distribution, average tuber weight, and marketable, unmarketable, and total tuber yields.

2.5.1. Days to Flowering and Maturity (Days). Days to flowering in each plot was recorded by counting the number of days elapsed from the time of planting up to the time when $50 \%$ of the plants in the plot flowered. Similarly, the maturity date was recorded by counting the number of days elapsed from the time of planting up to the time when the haulm of $90 \%$ of the plants in the plot dried.

2.5.2. Plant Height $(\mathrm{cm})$. It was collected by measuring the plant heights from the soil surface to the tip of the main stem of ten randomly selected plants using a ruler at physiological maturity of the crop, and the mean values in centimeter were computed for further analysis.

2.5.3. Tuber Yield ( $t$ ha-1). Tubers free from mechanical, disease, and insect pest damages and medium to large in size were considered as marketable. On the other hand, damaged and small-sized tubers were considered as unmarketable as described by [27]. The weights of such tubers obtained from the net plot area of each plot were measured in kilogram using a scaled balance and expressed in t ha- 1 and considered as marketable yield as well as unmarketable tuber yield. Finally, the total tuber yield in $\mathrm{t}$ ha- 1 was obtained from the sum of marketable and unmarketable yields.

2.5.4. Tuber Number per Hill. This was recorded as the actual number of tubers collected from randomly selected 10 plants in net plot area at the time of harvesting and calculated as an average tuber number.

Tuber weight (kg tuber-1) was recorded from randomly selected 10 plants of net plot area and determined by dividing the total fresh tuber yield to their respective total tuber number.
The collected data were subjected to analysis of variance using SAS statistical software [28]. The difference between treatments means were compared using least significant difference (LSD) at 5\% level of significance. Moreover to determine the economic feasibility of the treatments, partial budget analysis was done according to the procedures developed by CIMMYT (1988).

\section{Result and Discusion}

3.1. Crop Phenology and Growth Parameters. Neither the main effects of inter-row spacing nor the interaction of NPS fertilizer rate and inter-row spacing significantly affected the number of days to $50 \%$ flowering and days to $90 \%$ maturity. However, phonological parameters were highly significantly $(P<0.01)$ affected by the NPS fertilizer rate. The maximum period required to reach days to $50 \%$ flowering (60 days) and days to $90 \%$ maturity (104.87 days) was recorded from the application of $250 \mathrm{~kg} / \mathrm{ha}$ NPS which were statistically similar with the application of $200 \mathrm{~kg} / \mathrm{ha}$ NPS. The shortest duration to $50 \%$ flowering (55.33 days) and $90 \%$ maturity (96.47 days) was recorded from unfertilized plots (Table 2).

Increasing rates of NPS fertilizer may promote the vegetative phase of potato plants that may in turn prolong flowering and maturity of the potato plant. This might be attributed from the increased $\mathrm{N}$ uptake from the applied NPS fertilizer that contributes to have excessive haulm development and in turn prolonged days required to attaining 50\% flowering and $90 \%$ maturity. The present result is in line with that of $[17,29]$ who reported that application of $\mathrm{N}, \mathrm{P}$, and $\mathrm{S}$ fertilizer showed significant effect on prolonging of time of maturity. Bewuketu [30] also reported that application of blended NPSZnB fertilizer delayed days to attain physiological maturity. Other researchers also reported that increasing fertilizer rates, including NPS prolonged days to flowering and maturity of potato and other vegetable crops in different agro-ecologies [31, 32]. Alemayehu et al. [33] and Biruk [34] also indicated that increasing $\mathrm{N}$ and $\mathrm{P}$ fertilization levels significantly delayed days required to reaching flowering and maturity in potatoes.

Plant height of potato was highly significantly $(P<0.01)$ influenced by NPS fertilizer rates and inter-row spacing but not affected by the interaction. Application of NPS fertilizer at the rate of $250 \mathrm{~kg} / \mathrm{ha}$ and $200 \mathrm{~kg} / \mathrm{ha}$ showed the highest 
TABLE 2: Main effects of inter-row spacing and NPS fertilizer rate on days to $50 \%$ flowering, days to $90 \%$ maturity and plant height.

\begin{tabular}{lccc}
\hline Treatments & 50\% flowering & 90\% maturity & $\begin{array}{c}\text { Plant } \\
\text { height }(\mathrm{cm})\end{array}$ \\
\hline Inter-row spacing $(\mathrm{cm})$ & & \\
45 & 58.11 & 99.94 & $83.056^{\mathrm{ab}}$ \\
55 & 58.00 & 99.94 & $83.500^{\mathrm{a}}$ \\
65 & 58.00 & 99.89 & $82.667^{\mathrm{b}}$ \\
75 & 57.94 & 99.00 & $81.611^{\mathrm{c}}$ \\
85 significance & $57.89 \mathrm{NS}$ & $100.22 \mathrm{NS}$ & $81.500^{\mathrm{c} * *}$ \\
LSD (0.05) & $\mathrm{NS}$ & $\mathrm{NS}$ & 0.6249 \\
\hline NPS fertilizer rate $(\mathrm{kg} / \mathrm{ha})$ & & \\
0 & $55.33^{\mathrm{c}}$ & $96.47^{\mathrm{e}}$ & $76.533^{\mathrm{e}}$ \\
50 & $55.47^{\mathrm{c}}$ & $97.07^{\mathrm{d}}$ & $78.267^{\mathrm{d}}$ \\
100 & $56.87_{\mathrm{b}}$ & $98.67^{\mathrm{c}}$ & $80.800^{\mathrm{c}}$ \\
150 & $60.00^{\mathrm{a}}$ & $98.87^{\mathrm{b}}$ & $85.400^{\mathrm{b}}$ \\
200 & $60.27^{\mathrm{a}}$ & $103.80^{\mathrm{a}}$ & $87.067^{\mathrm{a}}$ \\
250 significance & $60.00^{\mathrm{a} * *}$ & $104.87^{\mathrm{a} * *}$ & $86.733^{\mathrm{a} * *}$ \\
LSD (0.05) & 0.54 & 0.567 & 0.6845 \\
CV (\%) & 1.28 & 0.78 & 1.10 \\
\hline
\end{tabular}

${ }^{* *}=$ significant at $1 \%$ significance levels; $\mathrm{NS}=$ nonsignificant. $\operatorname{LSD}(0.05)=$ least significant difference at $5 \%$ level; $\mathrm{CV}=$ coefficient of variation; means in column followed by the same letters are not significantly different at $5 \%$ level of significance.

plant height of potato $(86.73 \mathrm{~cm}$ and $87.07 \mathrm{~cm})$, respectively, while the shortest plant height $(76.53 \mathrm{~cm})$ was observed on plants without NPS fertilizer (Table 3 ). Moreover, the interrow spacing of $55 \mathrm{~cm}$ gave significantly taller plants $(83.5 \mathrm{~cm})$ than wider inter-row spacing of $75 \mathrm{~cm}$ and $85 \mathrm{~cm}$ (Table 3). Plant height consistently decreased as inter-row spacing increased from $55 \mathrm{~cm}$ to $75 \mathrm{~cm}$.

Comparatively low solar interception by the crop canopy and competition for light at narrower inter-row spacing might have resulted in longer internodes and increased plant height. The significant increase in plant height observed by plants treated at higher rates of NPS fertilizer also could be due to the fact that $\mathrm{P}$ is required in large quantities in shoot and root tips where metabolism is high and cell division is rapid. Similarly, sulfur promotes the formation of chlorophyll, higher photosynthetic activity, vigorous vegetative growth, and taller plants [35]. In conformity, Gezahegn [36] reported that plant height increased in response to increased rate of $\mathrm{N}$ and $\mathrm{P}$ fertilizers, which could be related to the role of $\mathrm{N}$ in promoting vegetative growth and that of phosphate in favoring leaf expansion and stem elongation. It is also in line with the findings of other researchers where they found an increased height in the potato plant with the application of S-containing fertilizers $[17,18,37]$. Therefore, the combined effects of $\mathrm{N}, \mathrm{P}$, and $\mathrm{S}$ in NPS fertilizer increased the plant height of potato plants.

\subsection{Yield and Yield Components of Potato}

3.2.1. Average Tuber Weight and Tuber Number per Hill. Analysis of variance indicated that both the main effects of NPS fertilizer rate and inter-row spacing had highly significant $(P<0.01)$ effect on marketable tuber number and unmarketable tuber number. However, there was no significant interaction effect. Total tuber number and average tuber weight were significantly affected by inter-row spacing and NPS fertilizer rate, respectively. Significantly lower number of marketable tuber (7.65) and total tuber number (10.061) were found from $45 \mathrm{~cm}$ inter-row spacing, while the highest marketable tuber number (11.744) and total tuber number (13.144) were recorded from $75 \mathrm{~cm}$ interrow spacing. Both marketable tuber number and total tuber number were statistically the same for $75 \mathrm{~cm}$ and $85 \mathrm{~cm}$ inter-row spacing.

The production of higher marketable and total tuber number per hill in response to planting the seed tubers at wider and/or intermediate spacing may be attributed low competition between plants for growth factors such as moisture, nutrients, and light and the optimal utilization of the growth factors for photosynthesis and assimilation of carbohydrates to tubers. In agreement with the result of inter-row spacing, $[38,39]$ reported that planting potato at the wider spacing resulted in the production of higher numbers of marketable tubers/hill than the narrower spacing.

Furthermore, a significant difference in total tuber number was observed due to NPS fertilizer application. The highest marketable tuber number (11.627) and total tuber number (13.020) were obtained from the application of $200 \mathrm{~kg} / \mathrm{ha}$ of NPS fertilizer rate which is statistically the same with $250 \mathrm{~kg} / \mathrm{ha}$ and $150 \mathrm{~kg} / \mathrm{ha}$ of NPS rate. On the other hand, the lowest marketable tuber number (7.680) and total tuber number (10.140) was recorded from the control treatment (Table 4). Increasing NPS application from 0 to $200 \mathrm{~kg} / \mathrm{ha}$ increased both marketable and total tuber number, but the increment was significant up to the rate of $150 \mathrm{~kg}$ NPS above which statistically nonsignificant increment was observed.

The increase on marketable and total tuber number per hill with an increase in NPS rate could be due to the fact that $\mathrm{N}$ can trigger the vegetative growth for more photo-assimilate production, while $\mathrm{P}$ enhanced the development of roots for nutrient uptake. The improvement in yield attributes with the application of $S$ could be ascribed to its pivotal role in regulating physiological and metabolic system in plant. Sulfur enhances cell multiplication, elongation, and expansion; chlorophyll synthesis results in higher dry matter accumulation and consequently higher yield attributes [40].

In agreement with the present finding, the authors of [41] and [29] have reported a significant marketable and total tuber number increment in response to $\mathrm{N}$ and $\mathrm{P}$ fertilizer application. According to [35], sulfur resulted significant influence on yield parameters and yield of potato. They reported that the highest number of tuber per plant was recorded at $45 \mathrm{~kg} / \mathrm{ha}$ sulfur, which was significantly superior over control and $15 \mathrm{~kg} / \mathrm{ha}$ sulfur. Similarly, Singh et al. [42] reported that application of $180 \mathrm{~kg} \mathrm{~N}$ along with $50 \mathrm{~kg} \mathrm{~S}$ increased the number of tuber by $43 \%$. According to Solomon et al [43]. increasing NPS rate from 0-0-0 to 110 $19.74-50.8 \mathrm{~kg} / \mathrm{ha}$ of $\mathrm{N}-\mathrm{S}-\mathrm{P}_{2} \mathrm{O}_{5}$ increased the number of marketable tuber by $127 \%$.

Unmarketable tuber number per hill decreased with increasing inter-row spacing. The highest unmarketable 
TABLE 3: Main effects of inter-row spacing and NPS fertilizer rate on marketable tuber number/hill, unmarketable tuber number/hill, total tuber number/hill, and average tuber weight/tuber.

\begin{tabular}{|c|c|c|c|c|}
\hline Treatments & MTN & UTN & TTN & AWT(g) \\
\hline \multicolumn{5}{|c|}{ Inter-row spacing $(\mathrm{cm})$} \\
\hline 45 & $7.650^{\mathrm{d}}$ & $2.411^{\mathrm{a}}$ & $10.061^{\mathrm{c}}$ & $72.342^{\mathrm{b}}$ \\
\hline 55 & $8.789^{\mathrm{cd}}$ & $2.489^{\mathrm{a}}$ & $11.278^{\mathrm{bc}}$ & $72.663^{\mathrm{b}}$ \\
\hline 65 & $9.711^{\mathrm{bc}}$ & $1.539^{\mathrm{b}}$ & $11.250^{\mathrm{bc}}$ & $82.061^{\mathrm{a}}$ \\
\hline 75 & $11.744^{\mathrm{a}}$ & $1.400^{\mathrm{b}}$ & $13.144^{\mathrm{a}}$ & $85.559^{\mathrm{a}}$ \\
\hline 85 significance level & $11.378^{\mathrm{ab} * *}$ & $1.567^{\mathrm{b} * *}$ & $12.944^{\mathrm{ab} *}$ & $83.456^{\mathrm{a} * *}$ \\
\hline $\operatorname{LSD}(0.05)$ & 1.8498 & 0.5328 & 1.7347 & 8.1357 \\
\hline \multicolumn{5}{|c|}{ NPS fertilizer rate $(\mathrm{kg} / \mathrm{ha})$} \\
\hline 0 & $7.680^{\mathrm{d}}$ & $2.460^{\mathrm{a}}$ & $10.140^{\mathrm{b}}$ & $72.288^{\mathrm{b}}$ \\
\hline 50 & $8.893^{\mathrm{cd}}$ & $2.234^{\mathrm{a}}$ & $11.127^{\mathrm{ab}}$ & $73.399^{\mathrm{b}}$ \\
\hline 100 & $9.073^{\mathrm{bcd}}$ & $2.333^{\mathrm{a}}$ & $11.307^{\mathrm{ab}}$ & $77.597^{\mathrm{ab}}$ \\
\hline 150 & $10.853^{\mathrm{abc}}$ & $1.593^{\mathrm{b}}$ & $12.447^{\mathrm{a}}$ & $83.215^{\mathrm{a}}$ \\
\hline 200 & $11.627^{\mathrm{a}}$ & $1.393^{\mathrm{b}}$ & $13.020^{\mathrm{a}}$ & $83.493^{\mathrm{a}}$ \\
\hline 250 significance & $11.00^{\mathrm{ab} * *}$ & $1.373^{\mathrm{b} *}$ & $12.373^{\mathrm{a} *}$ & $85.304^{\mathrm{a} *}$ \\
\hline LSD $(0.05)$ & 2.0264 & 0.5836 & 1.9003 & 8.9122 \\
\hline CV (\%) & 28.13 & 32.45 & 22.15 & 15.39 \\
\hline
\end{tabular}

UMTN = number of unmarketable tubers; MTN=number of marketable tubers; TTN=number of total tubers. AWT=average weight of tuber; ${ }^{*}=$ significant at $5 \%$ significance levels; ${ }^{* *}=$ significant at $1 \%$ significance levels; LSD $(0.05)=$ least significant difference at $5 \%$ level; CV= coefficient of variation; means in column followed by the same letters are not significantly different at $5 \%$ level of significance.

TABLE 4: Main effects of inter-row spacing and NPS fertilizer rate on stand count percent, marketable tuber yield/ha, unmarketable tuber yield/ha, and total tuber yield/ha.

\begin{tabular}{|c|c|c|c|c|}
\hline Treatments & SCP & $\operatorname{MTY}(\mathrm{t} / \mathrm{ha})$ & UTY (t/ha) & TTY (t/ha) \\
\hline \multicolumn{5}{|c|}{ Inter-row spacing $(\mathrm{cm})$} \\
\hline 45 & 90.833 & $38.575^{\mathrm{b}}$ & $4.113^{\mathrm{a}}$ & $42.689^{\mathrm{b}}$ \\
\hline 55 & 94.722 & $42.684^{\mathrm{a}}$ & $3.842^{\mathrm{a}}$ & $46.526^{\mathrm{a}}$ \\
\hline 65 & 93.333 & $45.084^{\mathrm{a}}$ & $3.3767^{\mathrm{b}}$ & $48.462^{\mathrm{a}}$ \\
\hline 75 & 93.611 & $37.492^{\mathrm{b}}$ & $3.242^{\mathrm{b}}$ & $40.734^{\mathrm{b}}$ \\
\hline 85 significance level & 94.722 NS & $31.717^{* *}$ & $3.235^{\mathrm{b} * *}$ & $34.952^{\mathrm{c} * *}$ \\
\hline $\operatorname{LSD}(0.05)$ & NS & 3.7003 & 0.2897 & 3.7182 \\
\hline \multicolumn{5}{|c|}{ NPS fertilizer rate $(\mathrm{kg} / \mathrm{ha})$} \\
\hline 0 & 92.000 & $26.442^{\mathrm{c}}$ & $4.767^{\mathrm{a}}$ & $31.209^{c}$ \\
\hline 50 & 91.667 & $30.025^{c}$ & $3.693^{\mathrm{b}}$ & $33.719^{c}$ \\
\hline 100 & 94.667 & $36.908^{\mathrm{b}}$ & $3.332^{\mathrm{c}}$ & $40.239^{\mathrm{b}}$ \\
\hline 150 & 95.00 & $46.303^{\mathrm{a}}$ & $3.289^{c}$ & $49.594^{\mathrm{a}}$ \\
\hline 200 & 95.667 & $48.056^{\mathrm{a}}$ & $3.089^{c}$ & $51.145^{\mathrm{a}}$ \\
\hline 250 significance & $91.667 \mathrm{NS}$ & $46.929^{a * *}$ & $3.201^{* *}$ & $50.131^{\mathrm{a} * *}$ \\
\hline LSD $(0.05)$ & NS & 4.0535 & 0.3174 & 4.0731 \\
\hline $\mathrm{CV}(\%)$ & 7.16 & 14.94 & 12.19 & 13.70 \\
\hline
\end{tabular}

$\mathrm{SCP}=$ stand count percent; UMTY $=$ yield of unmarketable tuber; $\mathrm{MTY}=$ yield of marketable tuber; TTY $=$ total tuber yield; ${ }^{* *}=$ significant at $1 \%$ significance levels; LSD (0.05) = least significant difference at $5 \%$ level; CV= coefficient of variation; means in column followed by the same letters are not significantly different at $5 \%$ level of significance.

tuber number (2.411) was recorded at narrow inter-row spacing $(45 \mathrm{~cm})$ and the lowest $(1.567)$ was recorded at wider inter-row spacing $(85 \mathrm{~cm})$ which is statistically at par with $65 \mathrm{~cm}$ and $75 \mathrm{~cm}$. Production of high number of unmarketable tubers at narrower spacing may be due to the fact that narrower planting may result in the production of large numbers of stems per unit area, which may lead to stiff competition among plants and tubers for growth factors, rendering the tubers small-sized and underdeveloped. However, wider spacing may result in the production of smaller number of stems per unit area, thereby reducing the competition of growth factors among plants and tubers and leading to the production of large-sized tubers. This suggestion is in accordance with that of [44] who described that narrower spacing resulted in the production of many stems with many small-sized tubers, whereas wider spacing results in the production of a fewer stems per unit area resulting in the production of fewer large-sized tubers. According to Girma et al. [38, 39], planting potato at the narrower spacing resulted in the production of higher numbers of unmarketable tubers than the wider spacing.

The maximum number of unmarketable tuber (2.46) was recorded from unfertilized treatment which was statistically at par with the application of $50 \mathrm{~kg} / \mathrm{ha}$ and $100 \mathrm{~kg} / \mathrm{ha}$ NPS 
fertilizer, whereas the minimum number of unmarketable tuber number was recorded from $200 \mathrm{~kg} / \mathrm{ha}$ NPS fertilizer rate. Moreover, the authors of [29] and [42] reported that application of $\mathrm{N}-, \mathrm{P}-$, and S-containing fertilizers increased production of marketable tubers and decreased unmarketable tubers.

The highest tuber weight $(85.56 \mathrm{~g})$ of potato was recorded at $75 \mathrm{~cm}$ inter-row spacing and the lowest tuber weight $(72.34 \mathrm{~g})$ was recorded at $45 \mathrm{~cm}$ inter-row spacing. Average tuber weight was statistically similar for inter-row spacing of $65 \mathrm{~cm}, 75 \mathrm{~cm}$, and $85 \mathrm{~cm}$ (Table 4). The production of tubers with maximum tuber weight recorded with intermediate and wider spacing might be due to the production of optimum number of stems with lesser competition for resource between plants as compared to closer plant spacing. This implies that an increase in density probably causes an increase in competition between and within plants and hence leads to decrease in availability of nutrients to each plant and, consequently, results in decline of mean tuber weight. In line to this study, Arega [38] reported that maximum average tuber weight was recorded for plants planted at intermediate and wider plant spacing, and the lowest result was obtained at closer plant spacing.

Furthermore, a significant difference in average tuber weight was observed due to NPS fertilizer application. The highest average tuber weight $(83.49 \mathrm{~g})$ was obtained from the application of 200 NPS fertilizer. However, this result was statistically similar with the application of $150 \mathrm{~kg} / \mathrm{ha}$ and $250 \mathrm{~kg} / \mathrm{ha}$ NPS fertilizer. On the other hand, the lowest average tuber weight $(72.29 \mathrm{~g})$ was recorded from the control treatment (Table 4). Average tuber weight increment with increasing fertilizer rate up to optimal was also reported by different authors. Nigusie [45] reported significant response of average tuber weight production of potato with an increased level of $\mathrm{N}$ and $\mathrm{P}$ nutrients. Application of NPS fertilizer produced the biggest tuber of potato than the control treatment [17]. According to Solomon et al., [43] application of $9.87 \mathrm{~kg} / \mathrm{ha} \mathrm{S}_{2}$ with $55-25.4 \mathrm{~kg} / \mathrm{ha} \mathrm{N}_{2} / \mathrm{P}_{2} \mathrm{O}_{5}$ doubled the size of average tuber weight as compared with unfertilized plant.

3.2.2. Tuber Yield. Marketable, unmarketable, and total tuber yield among inter-row spacing and NPS fertilizer rates were highly significant $(p<0.01)$. However, their interaction was found nonsignificant. Maximum marketable and total tuber yield was obtained at medium or intermediate interrow spacing than wider plant spacing. The highest marketable tuber yield $(45.084 \mathrm{t} / \mathrm{ha})$ and total tuber yield $(48.462 \mathrm{t} / \mathrm{ha})$ was obtained from intermediate or medium $(65 \mathrm{~cm})$ inter-row spacing, whereas the lowest marketable yield $(31.717 \mathrm{t} / \mathrm{ha})$ and total tuber yield $(34.952 \mathrm{t} / \mathrm{ha})$ were recorded at the wider inter-row spacing $(85 \mathrm{~cm})$. Both marketable and total tuber yield was statistically similar for inter-row spacing of $65 \mathrm{~cm}$ and $55 \mathrm{~cm}$ (Table 5).

The increase in total tuber yield at intermediate interrow spacing might be attributed to efficient use of available soil nutrients and other growth factors and enables to produce more tubers at the higher plant population per
TABLE 5: Main effects of inter-row spacing and NPS fertilizer rate on tuber size distribution.

\begin{tabular}{lcccc}
\hline Treatments & VSST (\%) & SST (\%) & $\begin{array}{c}\text { MST } \\
(\%)\end{array}$ & LST (\%) \\
\hline Inter-row spacing $(\mathrm{cm})$ & $12.632^{\mathrm{a}}$ & $21.393^{\mathrm{a}}$ & 42.294 & $23.681^{\mathrm{c}}$ \\
45 & $10.692^{\mathrm{a}}$ & $17.796^{\mathrm{ab}}$ & 39.776 & $31.736^{\mathrm{b}}$ \\
55 & $6.440^{\mathrm{b}}$ & $15.312^{\mathrm{bc}}$ & 43.436 & $34.868^{\mathrm{ab}}$ \\
65 & $6.773^{\mathrm{b}}$ & $12.981^{\mathrm{c}}$ & 39.663 & $40.583^{\mathrm{a}}$ \\
75 & $6.936^{\mathrm{b} * *}$ & $13.546^{\mathrm{bc} * *}$ & 42.339 & $37.179^{\mathrm{ab} * *}$ \\
85 significance & 3.9867 & 4.5827 & $\mathrm{NS}$ & 7.0599 \\
level & $17.421^{\mathrm{a}}$ & $21.102^{\mathrm{a}}$ & 37.396 & $24.081^{\mathrm{d}}$ \\
LSD (0.05) & $13.427^{\mathrm{a}}$ & $20.927^{\mathrm{a}}$ & 40.000 & $25.646 \mathrm{c}^{\mathrm{d}}$ \\
NPS fertilizer rate & $(\mathrm{kg} / \mathrm{ha})$ & & & \\
0 & $8.089^{\mathrm{b}}$ & $16.717^{\mathrm{ab}}$ & 42.169 & $33.026^{\mathrm{bc}}$ \\
50 & $6.844^{\mathrm{b}}$ & $14.087^{\mathrm{b}}$ & 40.506 & $38.563^{\mathrm{ab}}$ \\
100 & $5.803^{\mathrm{b}}$ & $12.360^{\mathrm{b}}$ & 39.944 & $41.893^{\mathrm{a}}$ \\
150 & $5.984^{\mathrm{b} * *}$ & $12.041^{\mathrm{b} * *}$ & 43.595 & $38.447^{\mathrm{ab} * *}$ \\
200 & 4.3672 & 5.0201 & $\mathrm{NS}$ & \\
250 significance & 38.49 & 35.42 & 21.54 & 31.7337 \\
LSD (0.05) & CV (\%) & &
\end{tabular}

VST=very small-sized tuber number (\%); SST=small-sized tuber number (\%); MST =medium-sized tuber number (\%); LST = large-sized tuber number $(\%) ;{ }^{* *}=$ significant at $1 \%$ significance levels; LSD $(0.05)=$ least Significant Difference at $5 \%$ level; CV $=$ coefficient of variation; means in column followed by the same letters are not significantly different at $5 \%$ level of significance.

hectare in plants grown at optimum plant spacing than closer and wider plant spacing. Increased plant population increased yield due to more tubers being harvested per unit area of land [46]. This result was in agreement with the findings of Harnet et al. [12] who reported that the highest marketable and total tuber yield was recorded at $65 \mathrm{~cm}$ interrow spacing and the lowest was recorded at $80 \mathrm{~cm}$ inter-row spacing. The authors of [11] and [47] also reported that closer and intermediate spacing of $50 \mathrm{~cm} \times 25 \mathrm{~cm}$ and $60 \mathrm{~cm} \times 25 \mathrm{~cm}$ produced higher marketable and total tuber yield, whereas wider spacing of $80 \mathrm{~cm} \times 30 \mathrm{~cm}$ and $75 \mathrm{~cm} \times 30 \mathrm{~cm}$ led to the production of lower marketable tuber yields. Furthermore, Zabihi et al. [48] reported that plant density in potato affects some of the important plant traits such as total yield, tuber size distribution, and tuber quality. Increase in plant density led to decrease in mean tuber weight, but number of tubers and yield per unit area were increased.

On the contrary to this finding, Birahanu and Woldegiorgis reported that wider spacing of $75 \mathrm{~cm} \times 30 \mathrm{~cm}$ was appropriate for high yield of potato. In addition, the authors of [39] indicated that the marketable tuber yields of plants cultivated at the spacing of $85 \mathrm{~cm}$ between rows and $30 \mathrm{~cm}$ between plants exceeded the total tuber yield and marketable tuber yields of plants grown at the spacing of $65 \mathrm{~cm}$ between rows and $30 \mathrm{~cm}$ between plants. Generally, these contradictions from the present study result indicated that optimum spacing may vary with variety, soil, climate, and other environmental factors for the same crop.

Application of NPS fertilizer at the rate of $200 \mathrm{~kg} / \mathrm{ha}$ produced the highest marketable tuber yield $(48.056 \mathrm{t} / \mathrm{ha})$ 
and total tuber yield $(51.145 \mathrm{t} / \mathrm{ha})$, while the lowest marketable tuber yield $(26.442 \mathrm{t} / \mathrm{ha})$ and total tuber yield $(31.209 \mathrm{t} / \mathrm{ha})$ were obtained from non-NPS-treated plots (Table 4). The yield increment due to NPS fertilizer application was significant up to $150 \mathrm{~kg} / \mathrm{ha}$ above which nonsignificant increment was observed. The difference in marketable and total tuber yield between the application rate of $150 \mathrm{~kg} / \mathrm{ha}, 200 \mathrm{~kg} / \mathrm{ha}$, and $250 \mathrm{~kg} / \mathrm{ha}$ NPS fertilizer was nonsignificant (Table 5).

Different scholars indicated that application of $\mathrm{P}$ [29, 49-51]; S [52, 53]; NP [38, 54]; and NS [42] exhibited a significant increment on marketable and total tuber yield of potato plant. In addition, an increase of potato tuber yields with increasing levels of NPS in different areas of Ethiopia was reported by $[15,17,18,32,55,56]$. Reference [38] showed that the increased level of $\mathrm{N}$ and $\mathrm{P}$ fertilizer from 0 to $110 \mathrm{~N}_{2}$ with $90 \mathrm{~kg} / \mathrm{ha} \mathrm{P}_{2} \mathrm{O}_{5}$ increased the marketable yield by $131 \%$ and addition of $20 \mathrm{~kg} \mathrm{~S} /$ ha over NP raised the marketable yield by $153 \%$.

$P$ nutrient from NPS might enhance the development of roots particularly lateral and fibrous rootlets which in turn contributed to nutrient absorption, photosynthesis, and general physiological processes. Potato tuber yield is also known to be influenced by $\mathrm{P}$ fertilizers through its effect on the number of tubers produced, the size of the tubers, and the time at which the maximum yield is obtained [50, 51]. They showed that yield response to increasing levels of $\mathrm{P}$ fertilizer was generally positive up to a particular level, above which the response became negative. References [29, 49] also reported that increasing $\mathrm{P}$ application increased total tuber yield.

The increase in tuber yield with increasing sulfur levels may be due to its role in synthesis of sulfur-containing amino acids, proteins, energy transformation, and activation of enzymes which in turn enhances carbohydrate metabolism and photosynthetic activity of plant with increased chlorophyll synthesis [57] and partitioning of the photosynthates in the shoot and tubers [58]. Application of sulfurcontaining fertilizers like NPS improves availability of plant nutrients such as $\mathrm{P}, \mathrm{Fe}, \mathrm{Mn}$, and $\mathrm{Zn}$, by amending the soil $\mathrm{pH}$ that may in turn increase yields of vegetable crops including potato [59]. According to [53], application of S fertilizer resulted significant differences on yield and raising the level 0 to $45 \mathrm{~kg} / \mathrm{ha}$ increased total tuber yield per plant by $32.55 \%$. Reference [52] reported S fertilizer contributed to a significant increment of potato tuber yield through enlarging tuber weight.

With an increase of inter-row spacing, nonmarketable tuber yield decreased where the highest unmarketable tuber yield $(4.113 \mathrm{t} / \mathrm{ha})$ was recorded at $45 \mathrm{~cm}$, whereas the lowest $(3.235 \mathrm{t} / \mathrm{ha})$ was recorded from $85 \mathrm{~cm}$. This might be due to the fact that closer spaced plants may have high competition for growth factors due to high plant number per unit area than wider plant spacing which led to produce high number of undersized tubers and unmarketable tuber yield. Similarly, the authors of $[38,39]$ found that plants grown at closer spacing produced high unmarketable tuber yield than plants grown at wider plant spacing.

With respect to NPS fertilizer rate, unmarketable tuber yield decreased with increase in NPS fertilizer rate, where the lowest unmarketable tuber yield (3.089 t/ha) was recorded at $200 \mathrm{~kg} / \mathrm{ha}$ NPS fertilizer rate and the highest unmarketable tuber yield $(4.767 \mathrm{t} / \mathrm{ha})$ was recorded at the control treatment (Table 4). In line with this result, Minwuyelet [17] reported that potato plants without NPS fertilizer produced the highest unmarketable tuber yield of $2.4 \mathrm{t} / \mathrm{ha}$ while those supplied with the highest NPS fertilizer rate produced the lowest unmarketable tuber yield of $0.50 \mathrm{t} / \mathrm{ha}$.

\subsubsection{Tuber Size Distribution. Main effect of NPS fertilizer} rate and inter-row spacing showed highly significant $(P<0.01)$ effect on tuber size distribution (very small-sized tuber, small-sized tubers, and large-sized tuber number) except for medium-sized tubers. However, their interaction effect was not significant (Table 6). Maximum number of very small-sized tuber $(12.632 \%)$ and small-sized tuber $(21.393 \%)$ was obtained from $45 \mathrm{~cm}$, while the lowest numbers of very small-sized tubers $(6.440 \%)$ and small-sized tuber number (12.981\%) were recorded from $65 \mathrm{~cm}$ to $75 \mathrm{~cm}$, respectively. However, there was no significant difference in both very small- and small-sized tuber numbers which was between 85,75 , and $65 \mathrm{~cm}$ inter-row spacing.

The probable reasons behind the decrease in number of small-sized tubers at increasing inter-row spacing might be due to high interspecific competition at high plant density. Increase in density may increase the competition between and within the plants and hence lead to decrease in the availability of nutrients for each plant. As a result, there would be a decline in mean tuber weight [60]. This result was in agreement with the finding of Wiersema [61] who reported that, at higher stem density, the tuber produced will remain smaller than at lower stem densities. Reference [62] also reported that increase in plant density decreases mean tuber size probably because of plant nutrient elements reduction increases in interspecies competition and large number of tubers produced by high number of stems. Reference [12] also reported a high proportion of very smallsized tubers produced from the narrow spacing than wider spacing. According to [11], the maximum yield of very small-sized tubers was recorded for high planting density, and low yield was recorded for low planting density.

With respect to the NPS fertilizer rate, the lowest numbers of very small-sized tuber $(5.803 \%)$ and small-sized tuber number $(12.041 \%)$ were obtained from the application of $200 \mathrm{~kg} / \mathrm{ha}$ and $250 \mathrm{~kg} / \mathrm{ha}$ of NPS fertilizer, respectively, whereas the highest numbers of very small-sized tubers $(17.421 \%)$ and small-sized (21.102\%) tubers were recorded at the control treatment. Increasing NPS fertilizer rate from 0 to $200 \mathrm{~kg} / \mathrm{h}$ a showed linear and consistent decrement in very small- and small-sized tuber number though there was no significant difference between $250 \mathrm{~kg} / \mathrm{ha}, 200 \mathrm{~kg} / \mathrm{ha}$, and $150 \mathrm{~kg} / \mathrm{ha}$ (Table 6). The decrement in the proportion of small-sized tubers due to fertilizer rate increment was also reported by [49]. Main effect of the NPS fertilizer rate and inter-row spacing did not show significant difference on medium-sized tuber distribution. Though nonsignificant difference was observed, the highest percent of mediumsized tubers was recorded at an inter-row spacing of $65 \mathrm{~cm}$. 
TABLE 6: Partial budget analysis data for NPS fertilizer rate.

\begin{tabular}{lccccc}
\hline NPS rate $(\mathrm{kg} / \mathrm{ha})$ & AMTY (t/ha) & AMTY (t/ha) & GFB (ETB/ha) & TVC (ETB/ha) & NB (ETB/ha) \\
\hline 0 & 26.442 & 23.7978 & 118989 & 0 & 118989 \\
50 & 30.025 & 27.0225 & 135112.5 & 1460 & 133652.5 \\
100 & 35.908 & 33.2172 & 166086 & 2420 & 1004.35 \\
150 & 45.303 & 41.6727 & 208363.5 & 3380 & 3126.41 \\
200 & 48.056 & 43.2504 & 216252 & 4340 & 204983.5 \\
250 & 46.929 & 42.2361 & 211180.5 & 5300 & 211912 \\
\hline
\end{tabular}

Note. AMTY $=$ average marketable tuber yield; ATY $=10 \%$ adjusted tuber yield; GFB $=$ gross field benefit; TVC $=$ total variable cost; $\mathrm{MRR}=$ marginal rate of return; $\mathrm{NB}=$ net benefit,

The highest mean percent of large-sized tuber $(40.583 \%)$ was obtained from $75 \mathrm{~cm}$, but was not statistically different from $65 \mathrm{~cm}$ to $85 \mathrm{~cm}$ inter-row spacing (Table 6). Moreover, the lowest percent of large-sized tuber $(23.681 \%)$ was recorded at the narrowest inter-row spacing of $45 \mathrm{~cm}$. Furthermore, as NPS fertilizer rate increased from $0 \mathrm{~kg} / \mathrm{ha}$ to $200 \mathrm{~kg} / \mathrm{ha}$, the number of large-sized tuber increased consistently, where the highest percent of small-sized tubers $(41.893 \%)$ was recorded at $250 \mathrm{~kg} / \mathrm{ha}$ NPS fertilizer rate, while the lowest proportion (24.081\%)) was obtained from the control treatment. NPS rates from $150-250 \mathrm{~kg} / \mathrm{ha}$ had statistically the same effect on proportion of large-sized tubers.

3.3. Economic Analysis. According to [63], the partial budget analysis includes the total variable costs and net benefits of each treatment. In this study, the costs of fertilizer and cost for transporting and application varied, while other costs were constant for each treatment. Therefore, the fertilizer and labor-related costs, gross incomes, net benefit, and associated net return are presented in Table 6. Overall benefits of application of NPS fertilizer on potato exceed nonapplication both in yields and net benefits. Application of 200 and $250 \mathrm{~kg} / \mathrm{ha}$ NPS fertilizer recorded the $1^{\text {st }}$ and $2^{\text {nd }}$ highest net benefits, while application of $150 \mathrm{~kg} / \mathrm{ha}$ NPS fertilizer recorded the $3^{\text {rd }}$ highest net benefit of potato. Overall, the highest marginal rate of return was obtained from the application of $150 \mathrm{~kg} / \mathrm{ha}$ of the NPS fertilizer rate (Table 6).

\section{Conclusion}

Information regarding optimum spacing and nutrient rates for potato production deserves growers' attention as it is influenced by soil fertility status, crop variety, soil moisture status, and their interaction. Thus, agronomic and economic responses of potato under varying inter-row spacing and NPS fertilizer rates were investigated in Kechi research farm, Dawro zone of south-western Ethiopia. The result revealed that growth and yield parameters were significantly affected only by main effects of NPS rates and inter-row spacing. Application of $200 \mathrm{~kg}$ NPS/ha resulted maximum marketable tuber yield ( $48.056 \mathrm{t} / \mathrm{ha})$ and total tuber yield $(51.145 \mathrm{t} /$ ha) in which it resulted about $82 \%$ and $64 \%$ advantage over unfertilized plot, respectively. Furthermore, the highest marketable tuber yield $(45.084 \mathrm{t} / \mathrm{ha})$ and total tuber yield $(48.462 \mathrm{t} / \mathrm{ha})$ were obtained from the inter-row spacing of
$65 \mathrm{~cm}$ which was statistically at par with $55 \mathrm{~cm}$, whereas the lowest result for these parameters were recorded at $85 \mathrm{~cm}$. In terms of economic performance, $150 \mathrm{~kg} / \mathrm{ha}$ NPS was found to show the highest marginal rate of return (4303.91\%). Therefore, potato growing farmers are advised to apply 150 NPS $\mathrm{kg} / \mathrm{ha}$ with an inter-row spacing of $55 \mathrm{~cm}$ or $65 \mathrm{~cm}$. Further study considering other potential varieties, seasons, and locations are suggested.

\section{Data Availability}

The data used to support the findings of this study are available from the corresponding author upon request.

\section{Conflicts of Interest}

The authors declare that they have no conflicts of interest.

\section{Acknowledgments}

The authors would like to thank Wolaita Sodo University for providing funds and facilities to conduct the research. The authors are also grateful to Kechi district agriculture office, the experts, and the participating farmers for their cooperation in the project.

\section{References}

[1] FAOSTAT (Food and Agricultural Organization Statistic), World Food and Agricultural Organization Data of Statistics, FAO, Rome, Italy, 2015.

[2] FAO Food Agriculture Organization, Potato World: Production and Consumption, FAO Food Agriculture Organization, Rome, Italy, 2015.

[3] FAOSTAT, Statistical Database, Food and Agricultural Organization of United Nations, Rome, Italy, 2020.

[4] International Potato Center CIP, "Potato facts and figures," 2020, https://cipotato.org/potato/.

[5] Central Statistic Agency CSA, Agricultural Sample Survey: Area and Production of Major Crops, Central Statistic Agency, Dire Dawa, Ethiopia, 2018.

[6] FAOSTAT (Food and Agricultural Organization Statistic), World Food and Agricultural Organization Data of Statistics, FAO, Rome, Italy, 2019.

[7] M. Alemayehu, F. Tessafa, S. Bizuayehu, and B. Ayele, Amhara Region Horticulture Development Strategy (2015- 2019) (Working Document), Bureau of Agriculture, Bahir Dar, Ethiopia, 2015. 
[8] T. Tekalign, Response of potato to paclobutrazol and manipulation of reproductive growth under tropical conditions, $\mathrm{PhD}$ thesis, Bahir Dar University, Bahir Dar, Ethiopia, 2005.

[9] P. W. Matthews, E. L. Armstrong, C. J. Lisle, I. D. Menz, P. L. Shephard, and B. C. Armstrong, "The effect of faba bean plant population on yield, seed quality and plant architecture under irrigation in southern NSW," Australia Crop Agronomy Journal, vol. 2, no. 20, pp. 30-40, 2001.

[10] B. B. Singh, O. L. Chamblis, and B. Sharma, Advance in Cowpea Research, Co publication of International Institute of Tropical Agriculture and Japan International Research Center for Agricultural Science, Ibadan Nigeria, 1997.

[11] B. Tesfa, D. Nigussie, and T. Tamado, "Influence of plant spacing on seed and ware tuber production of potato (Solanum tuberosum L.) cultivars grown in eastern Ethiopia," Science, Technology and Arts Research Journal, vol. 4, no. 3, pp. 11-17, 2015.

[12] A. Harnet, B. Derbew, and W. Gebremedhin, "Effect of inter and intra-row spacing on seed tuber yield and yield components of potato (Solanum tuberosum L.) at Ofla Woreda, Northern Ethiopia," African Journal of Plant Science, vol. 8, no. 6, pp. 285-290, 2014.

[13] L. Fanuel, K. Kibebew, and S. Hailu, "Potassium (K) to Magnesium (Mg) ratio, its spatial variability and implications to potential Mg-Induced K Defciency in Nitisols of Southern Ethiopia," Agriculture \& Food Security, vol. 7, p. 13, 2018.

[14] EthioSIS Ethiopian Soil Information System, Soil Analysis Report, Agricultural Transformation Agency, Addis Ababa, Ethiopia, 2013.

[15] S. Boke, "Effects of organic and inorganic fertilizer application on potato yield and soil properties on alisols of chencha," Africa Journal of Science, vol. 2, no. 8, pp. 123-132, 2014.

[16] L. Fanuel, "Carbon stock, sequestration and soil properties among field in smallholder farms in southern Ethiopia," Environmental Science Research, vol. 9, p. 16, 2020.

[17] A. Melkamu and Minwyelet, "Optimum rates of NPS fertilizer application for economically profitable production of potato varieties at Koga Irrigation Scheme, Northwestern Ethiopia Cogent," Food \& Agriculture, vol. 4, pp. 14-39, 2018.

[18] M. Mekides, A. Melkamu, S. Getachew, and H. Amare, "Effects of blended NPS fertilizer rates on yield and yield components of potato (Solanum tuberosum L.) varieties at Dessie Zuria district, Northeast Ethiopia," Cogent Food \& Agriculture, vol. 6, no. 1, Article ID 1779478, 2020.

[19] PDAV Power Data Access Viewer, "NASA," 2020, https:// power.larc.nasa.gov/data-access-viewer/.

[20] J. G. Bouyoucos, "Hydrometer method improved for making particle size analyses of soils," Agronomy Journal, vol. 54, no. 5, pp. 464-465, 1962.

[21] L. P. Van Reeuwijk, "Procedures for soil analysisp international soil reference and information center (ISRIC), wageningen, Netherlands, walkley J. A, and Black A. I,1934. "Estimation of soil organic carbon by the chromic acid titration method," Soil Science, vol. 37, no. 1, pp. 29-38, 1992.

[22] J. M. Bremner, "Determination of nitrogen in soil by the kjeldahl method," The Journal of Agricultural Science, vol. 55, no. 1, pp. 11-33, 1960.

[23] A. Mehlich, "Mehlich 3 soil test extractant: a modification of mehlich 2 extractant," Communications in Soil Science and Plant Analysis, vol. 12, no. 15, pp. 1409-1416, 1984.

[24] EthioSIS Ethiopia Soil Information System, "Soil fertility status and fertilizer recommendation atlas for Tigray regional state, Addis Ababa, Ethiopia," Agricultural Transformation Agency, vol. 76, 2014.
[25] J. R. Landon, Booker Tropical Soil Manual: A Handbook for Soil Survey and Agricultural Land Evaluation in the Tropics and Subtropics, Longman Scientific and Technical, Essex, England, 1991.

[26] Ethiopia Institute of Agricultural Research EIAR, Crop Technologies Guideline, Ethiopian Institute of Agricultural Research, Addis Ababa, Ethiopia, 2007.

[27] A. Tesfaye, W. Shermari, and T. Thunya, "Evaluation of specific gravity of potato varieties in Ethiopia as criterion for determining processing quality," Kasetsart Journal, vol. 47, no. 1 , pp. 30-41, 2013.

[28] SAS Statistical Analysis Institute, SAS User Guides Version 9.1, SAS Inc, Cary. NC, USA, 2004.

[29] Z. Israel, M. Ali, and T. Solomon, "Effect of different rates of nitrogen and phosphorus on yield and yield components of potato (Solanum tuberosum L.) at Masha district, Southwestern Ethiopia," International Journal of Soil Science, vol. 7, no. 4, pp. 146-156, 2012.

[30] B. G. Bekele, "Effect of blended NPSZnB fertilizer and cattle manure rates on growth, yield and quality of potato (Solanum Tuberosum L.) at Banja District, Awi Zone, North Western Ethiopia," International Journal of Research Studies in Agricultural Sciences (IJRSAS), vol. 5, no. 5, pp. 27-36, 2019.

[31] D. K. Gebremeskel, "Assessment of production practices and effect of n:p2 o5 :s rates on yield and yield components of head cabbage (Brassica oleracea var. capitata) under irrigation conditions in lay armachio district, Amhara region, Ethiopia," MSc thesis, Bahir Dar University, Bahir Dar, Ethiopia, 2016.

[32] M. Mekashaw, "Assessment of farmer's production practices and effects of different rates of NPS fertilizer on yield and yield components of potato (Solanum tuberosum $\mathrm{L}$ ) variety under irrigated farming system in Dessie Zuria District, Amhara Region, Ethiopia," MSc Thesis, Bahir Dar University, Bahir Dar, Ethiopia, 2016.

[33] T. G. Alemayehu, D. Nigussie, and T. Tamado, "Response of potato (Solanum tuberosum L.) yield and yield components to nitrogen fertilizer and planting density at Haramaya, Eastern Ethiopia," Journal of Plant Sciences, vol. 3, no. 6, pp. 320-328, 2015.

[34] M. Biruk, D. Nigussie, T. Tamado, A. Yibekal, and A. Bekele, The Effects of Combined Application of Cattle Manure and NP Fertilizers on Yield and Nutrient Uptake of Potato in North Eastern Ethiopia, Department of Plant Science, College of Agriculture and Environmental Science, Haramaya University, Dire Dawa, Ethiopia, 2015.

[35] S. P. Sharma, A. S. Sandhu, R. D. Bhutani, and S. C. Khurana, "Effects of planting date and fertilizer dose on plant growth attributes and nutrient uptake of potato (Solanum tuberosum L.)," International Journal of Agricultural Sciences, vol. 4, no. 5, pp. 196-202, 2014.

[36] W. Gezahegn, "Response of potato (Solanum tuberosum 1.) to application of nitrogen, phosphorus, and farmyard manure at debark, northwestern Ethiopia," M.Sc. Thesis, Haramaya University, Alem Maya, Ethiopia, 2011.

[37] D. K. Sharma, S. S. Kushwah, and K. S. Verma, "Effect of sulphur on growth, yield and economics of potato cultivars," Annals of Plant and Soil Research, vol. 17, no. 1, pp. 45-49, 2015.

[38] A. Arega, A. Tekalign, T. Solomon, and B. Tekile, "Effect of inter and intra row spacing on tuber yield and yield components of potato (Solanum tuberosum L.) in guji zone, southern Ethiopia," Journal of Advancements in plant Science, vol. 1, p. 102, 2018. 
[39] C. Girma, C. Abebe, and C. Abebe, "Response of applied phosphorus fertilizer rate and plant spacing for potato (Solanum tuberosum L.) production on nitisols in central highland of Ethiopia," Greener Journal of Agricultural Sciences, vol. 7, no. 9, pp. 255-262, 2017.

[40] S. K. Singh and S. S. Lal, "Effect of potassium nutrition on potato yield, quality and nutrient use efficiency under varied levels of nitrogen application," Potato Journal, vol. 39, no. 2, pp. 155-165, 2012.

[41] M. F. Zamil, M. M. Rahman, M. G. Rabbani, and T. Khatun, "Combined effect of nitrogen and plant spacing on the growth and yield of potato with economic performance," Bangladesh Journal of Agricultural Research, vol. 3, pp. 1062-1070, 2010.

[42] H. Singh, S. Madhu, G. Aakash, and B. Monika, "Effect of nitrogen and sulphur on growth and yield attributes of potato (Solanum tuberosum L.)," International Journal of Physical and Social Sciences, vol. 9, no. 5, pp. 1-8, 2016.

[43] F. Solomon, A. Derajew, and T. Aleminew, "Effect of blended chemical fertilizer (sulfur, nitrogen and phosphorus) on yield and yield components of potato (Solanum tuberosum L.) in the rainy season," Journal of Horticulture and Forestry, vol. 11, no. 3, pp. 54-61, 2019.

[44] C. Lung'aho, B. Lemaga, M. Nyongesa et al., Commercial Seed Potato Production in Eastern and Central Africa, Kenya Agricultural Institute, Nairobi, Kenya, 2007.

[45] N. Abebe, "Effect of phosphorus and potassium fertilizer rates on yield and yield component of potato (Solanum tubersum $\mathrm{L}$,) at K/awlaelo, tigray, tigray agricultural research institute, mekelle, Ethiopia," Food Science and Quality Management, vol. 48, pp. 2016-2060, 2016.

[46] H. P. Beukema and D. E. Van der Zaag, Introduction to Potato Production, Pudoc Wageningen, Amsterdam, Netherland, 1990.

[47] D. Zebenay, D. Nigussie, and M. Wassu, "Influence of seed tuber size and plant spacing on yield and quality of potato (Solanum tuberosum L.) in holeta Central Ethiopia," M.Sc. Thesis, Haramaya University, Dire Dawa, Ethiopia, 2015.

[48] R. Zabihi-e-Mahmoodabad, S. Jamaati-e-Somarin, M. Khayatnezhad, and R. Gholamin, "Correlation of tuber yield with yield comonents of potato affected by nitrogen application rate in different plant density," Advances in Environmental Biology, vol. 5, no. 1, pp. 131-135, 2011.

[49] H. Mulubrhan, "The effects of nitrogen, phosphorus, and potassium fertilization on the yield and yield components of potato (Solanum tuberosum L.) grown on vertisol of mekelle area, Ethiopia," MSc Thesis submitted to the Faculty of the Department of Plant Science, School of Graduate Studies, and Alemaya University, Alemaya, Ethiopia, 2004.

[50] V. C. Sharma and B. R. Arora, "Effects of nitrogen, phosphorus, and potassium application on the yield of potato tubers (Solanum tuberosum L.)," The Journal of Agricultural Sciences, vol. 108, pp. 321-329, 1987.

[51] T. G. Sommerfeld and K. W. Knutson, "Effects of nitrogen and phosphorrus on the growth and development of Russet Burbank Potatoes grown in the Southeastern Idaho," American Potato Journal, vol. 42, pp. 351-360, 1965.

[52] B. Barczak, K. Nowak, and T. Knapowski, "Potato yield is affected by sulphur form and rate," Agrochimica, vol. 57, no. 4, pp. 363-372, 2013.

[53] D. K. Sharma, S. S. Kushwah, P. K. Nema, and S. S. Rathore, "Effect of sulphur on yield and quality of potato (Solanium tubersoum L.)," International Journal of Agricultural Research, vol. 6, no. 2, pp. 143-148, 2011.
[54] A. Zelalem, T. Takalign, and D. Nigussie, "Response of potato (Solanum tuberosum L.) to different rate of nitrogen and phosphorus fertilization on vertisols at Debre Birhan, in the central highlands of Ethiopia," African Journal of Plant Science, vol. 3, no. 2, pp. 16-24, 2009.

[55] M. Jemberie, "Effects of NPS fertilizer rate and irrigation frequency determination method on the growth and tuber yield of potato (Solanum tuberosum L) in Koga Irrigation Scheme, Northwestern Ethiopia," MSc thesis, Bahir Dar University, Bahir Dar, Ethiopia, 2017.

[56] A. Abewa and B. Agumas, "Response of irrigated potato (Solanum tuberosum L.) to nitrogen fertilizer at Koga irrigation scheme, West Gojjam," in Proceedings of the First Workshop on Agricultural Water Management Research and Development in Amhara Region, D. Gizaw, Ed., , Bahir Dar, Ethiopia, April 2012.

[57] I. M. Juszczuk and M. Ostaszewska, "Respiratory activity, energy and redox status in sulphur-deficient bean plants," Environmental and Experimental Botany, vol. 74, pp. 245-254, 2011.

[58] K. C. Sud and R. C. Sharma, "Sulphur needs of potato under rained conditions in Shimla Hills," Potato global research and development, vol. 2, pp. 889-899, 2002.

[59] H. Marschner, Mineral Nutrition of Higher Plants, Academic Press, Cambridge, MA, USA, 1995.

[60] D. I. Karafyllidis, D. N. Georgakis, N. I. Stavropoulos, E. X. Nianiou, and I. A. Vezyroglou, "Effect of planting density and size of potato seed-minitubers on their yielding capacity," Acta Horticulturae, vol. 462, pp. 943-950, 1997.

[61] Wiersema SG, Effect of Stem Density on Potato Production. Technical Information Bulletin 1, International potato center (CIP), Lima, Peru, 3rd edition, 1987.

[62] A. M. Khalafalla, "Effect of plant density and seed size on growth and yield of solanum potato in khartoum state, Sudan," African Crop Science Journal, vol. 9, no. 1, pp. 77-82, 2001.

[63] CIMMYT, From Agronomic Data to Farmer Recommendations: An Economics Training Manual. Completely Revised Edition, CIMMY, México-Veracruz, Mexico, 1998. 